\title{
MANIFESTATIONS OF THE REVENANT IN ESTONIAN FOLK TRADITION
}

\section{Eha Viluoja}

In Estonian folk tradition the dead ancestors were anticipated to visit their former homes in autumn during the so-called souls' time - hingedeaeg - observed regionally during a different period of time between Michaelmas (September

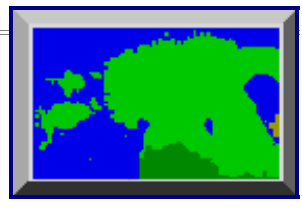
29) and Christmas (Loorits 1957, Hiiemäe 1990). The dead relatives visiting their homes at that time were called souls - hinged. However, it was believed that the dead could visit home also some other time, in this case it was considered to be a token that something had to be wrong. Such a dead returning home at a random time was called kodukäija (literally: home wanderer). The present paper will discuss the latter mythological being. The analysed material (belief references, legends, memorates) comes basically from the Estonian Folklore Archives in Tartu, in addition the collection of the Folklore Department of the Institute of Estonian Language (in Tallinn) has been consulted. Systematic collecting of folklore was initiated in Estonia in the last decades of the previous century and it continues up to date. In the Archives there are about 3,600 reference cards in the file of the revenant, the home-wanderer. Former studies, especially those by M. J. Eisen and O. Loorits, were also consulted. While grouping the descriptions of how the home-wanderer has been perceived, the following systematization was established.

\section{Visual revenant.}

1.1. References about encounters with the revenant, without providing the description.

1.2. The revenant in the form of a man (map 1) may look like the living person once looked and may wear the clothes he/she was buried with, or, he may be a stranger (the latter occurs especially when the revenant is seen by a casual person in a casual place, e.g. on the road). The colours mentioned most frequently are white (as the former colour of burial clothes), black, seldom grey, blue or red. The revenant can appear also partially: he just peeps into a room or thrusts in his hand so that one can guess the presence of the whole of him. But in some legends the dead is visible only as a body part (e.g. a sawing arm (ERA II 70, 316 (5) Rakvere)). The revenant have on him an item or a part of an item from the grave: a piece of the coffin, linen, bath whisk etc. The revenant may possess devilish attributes (unusual eyes, teeth, etc.). The relationship between the revenant and the devil, however, is a separate topic that I have discussed in an earlier study (Viluoja 1982). As a rule, the revenant is on foot, seldom has he come by a vehicle or on horseback. There are rare accounts about the dead floating or flying in the air. The gait of the revenant is either usual (sometimes, at that, very quick) or bobbing. The latter means jumping on one foot, or from one to another, or bouncing from one side of the road to the other.

1.3. The revenant in the form of an animal or a bird (map 2) is more rare than the one in the form of a man. It is but natural that hereby the domestic animals close to man are met. Among the 92 cases dogs are met in 35, cats in 17, goats in 9, cows in 7, horses in 6, pigs in 5, sheep and hares in 3 , an animal as such in 2, and a rabbit, a rat, a squirrel, a wolf and a bear each in 1 case. The dominant colours are black (18 times), white (12 times), red (10 times), next come grey (3 times), motley (3 times) and yellow (1 time). In about half of the accounts (45 times) the colour is not mentioned. 
Similarly to the man-shaped revenant, the one in the form of an animal may also look like an ordinary animal or possess various peculiar features. Sometimes the dead and the animal in the form of which he appears may share common features. Thus, a murdered merchant appears as an animal with bloody head (ERA II 19, 181 (13) Kose). The animal may appear together with some articles, for example, an ox is covered with a white linen (ERA II 257, 306 (16) Räpina, 1939). The constitution and colour of the animal need not be natural. A revenant in the form of an animal can also be visible only partially.

There are only a few references about slaughtered or dead animals haunting. Revenants in the shape of a bird are mentioned in the material analysed by me in 15 cases and include a goose ( 4 times), a hen (3 times), just a bird, a cuckoo and a crow (each twice), and a hawk and a raven (both once). The revenant in the form of a bird does not differ from an ordinary bird as far as the appearance is concerned. The colours mentioned include white (5 times), black (mentioned once), and in 9 cases the colour is not mentioned at all: it can be guessed that the colour does not deviate from the usual colour of the species.

Hereby I do not tackle the soul animals (hingeloom) - the beetle and the butterfly. The former has been associated with the revenant only once (ERA II 16, 470/1 (39) Kullamaa, 1929) and the latter occurs in the death dirges of the Setus, an ethnic group living in southeastern Estonia: "Fly home as a butterfly!"

1.4. The revenant in the form of a tree, a thing or a phenomenon. (map 3) A moving haystack as well as a moving fir-tree, a white stake or rolling grain sacks are frequently recognized as the dead visiting home. The revenant is also related with a vehicle (carriage, sledge, coach), especially in case there is something strange about the vehicle or it comes from the graveyard or approaches the house of mourning. The revenant is described as a vague figure (white, grey, black), a shadow or a cloud of mist. A whirlwind or a flurry and moving fire is thought to be a revenant.

\subsection{Changing and transforming revenant.}

One and the same dead may appear as different creatures or things at different times. But the transformation from one form into another may occur before the very eyes of the witness(es). At the transformation the borderlines between species may be preserved but transition from one species into another is possible too (e.g. a man may turn into an animal or a thing or vice versa, various combinations may occur). This however, characterizes supernatural creatures in general, like the sudden appearance and gradual or abrupt disappearance.

\section{Auditory revenant.}

\subsection{Rumbling and rustling. (map 4)}

In case an auditory impression about the revenant is described, the most frequent descriptions used are: the home-wanderer rumbles in the loft, byre or living rooms. The revenant may rumble by throwing things, pushing furniture upside down, etc. At closer examination it may turn out that actually all the things are as they should be - or everything is topsy-turvy. Things may move with the witnesses looking on.

The revenant is associated with knocks, footsteps, sounds of someone working (rattle of a handmill, sawing, ripple of milking in the byre, hammering in the smithy, etc.). Rustling of the clothes or the breathing of the revenant visiting his home may be heard. 


\subsection{Sounds. (map 5)}

Like the revenant's appearance, so the sounds he produces may be various beginning with ordinary human speech and ending with animal sounds and interjections. The sound made by the revenant is not always characterized in detail.

\subsubsection{Revenant's speech}

The speech of the revenant may be rendered in both indirect or direct speech. The latter is of special interest as it reveals that alongside with normal speech the revenant's language usage may be twisted, unclear or contain words from neighbouring languages. Revenant's talk may be a soliloquy, an address to a living person or a dialogue between the dead. A revenant in the form of an animal or a bird may also talk like a human being

\subsubsection{Singing.}

A revenant's song is usually made up of meaningless words and syllables, or he uses distorted language. Only seldom does it resemble a song proper (and makes use of alliteration, for example). In folk narratives only the text of the revenant's song is given, never the tune. The song, if it may be called so, consists of a few stanzas. Usually the revenant's singing is just mentioned. In comparison one may refer to the internationally spread legends about the divine service of the dead (Aa S 1; Simonsuuri C 1341), where the congregation of the dead sings church hymns.

\subsubsection{Other sounds.}

The revenant moans, shrieks, cries, laughs and whistles, he exclaims or makes onomatopoetic sounds. Different animal sounds are made by both the revenants in the form of a man and those in the form of an animal as well as invisible revenants. One and the same revenant may produce various sounds.

\section{Tactile revenant.}

The material in this group can be divided into two. A passive experiencer feels a touch or suffers from the aggressiveness of a revenant (blows, pinches, scratches). The revenant may be perceived as a nightmare. An active experiencer touches the revenant himself or attacks him (pushes, hits). Physical contact with the revenant is met in a number of legend types (e.g. Aa S 6, Aa S 35). It is often said that the revenant is cold. The revenant may be perceived as a gust of wind or a stir in the air

\section{Olfactory revenant.}

There are only rare references to smell perceptions (mostly the smell of decay) connected with revenant encounters.

The revenant may be described in folk tradition simultaneously as a visual, auditory, tactile or olfactory creature. On the other hand, one or all the mentioned properties may be absent, and only indirect proofs testify to the revenant's presence at the moment or a little earlier. 


\section{Indirect proofs of the revenant. (Map 6)}

Things moving about without evident reason, or the resistance of things may be interpreted as the result of the actions of the revenant (for example, the door would not close as if someone were holding it back (ERA II 9, 93 (12) Emmaste)). The dead can be associated with the mysterious light in the church, chapel, empty house or room.

The revenant need not leave traces: namely this is frequently the criterion of his supernatural character. At the same time, however, the traces can lead one to guess the presence of the revenant. Like the appearance of the revenant, so can also its traces be various: ordinary human footprints; a print of only one foot (sometimes the revenant is imagined as jumping); print of a human hand; tracks of animals: goat's, sheep's, hen's, goose's or horseshoe's print; one print made by a man, the other by a dog; marks of things (a pole, a potato hoe).

Once a thing put into the coffin of the dead or an article of clothes he/she was wearing is found, it is interpreted as a sign that the dead has left his grave and is wandering. The presence of the revenant can be deduced by the behaviour of animals: a dog can see things that a human being cannot, especially in case of the so-called four-eyed breed - the one with brown spots above it's eyes. The revenant is a mythological being known all over Estonia, as do show the maps of distribution added to the paper. On the maps the territory of Estonia is divided into parishes which is the proper unit for charting both linguistic and folk culture phenomena. Besides reflecting the actual distribution of the conception of the revenant it also reflects the intensity of collecting in one or another region. Therefore, numerous references from some parishes may be caused by the amount of informant correspondence received from the parish, and the absence or scantiness of other regions just testifies to the lack of information.

\section{Text example}

"There have passed 42 years since my mother died," tells us the mistress of Vana farmstead, Mai Kruusenberg. She is 67. "My mother was 65 when she died, and she told me this story. She worked as a servant in a village called Kärmu. The old mistress died there but returned to haunt her home, every night she let the cows and all in the byre loose, and messed up all the rooms in the house. Well, one evening the maid went to feed animals. Their four-eyed dog followed her to the byre. The dog was barking at one corner of the byre. And the maid tried to hush the dog down. After she had fed the animals, she took a stick or something from the floor and hit the dog, scolding, "What on earth are you barking at!" And the old woman answered from the corner, "That's right, Kaie, my good girl! Don't let it bite me!" The girl got scared and rushed off towards the house. They closed and bolted all the doors and windows. The home-wanderer loafed just about, then sometime at night she calmed down. But in the morning everything was topsy-turvy, and again all the animals in the byre were loose.

At the same night a man from Liigusta came from Haljala and he was drunk, you know. Just by the aspens near the Tõikvere inn he met the revenant and grabbed her straight by her jacket. The man tried to face the moon, because then he was stronger and won. But the revenant was struggling to face the moon, too - and when she succeeded, she tried to strangle the man. Well, then the man managed to turn towards the moon again, and using all his strength he knocked the revenant down. And turned then homewards, shouting: "Let the wolves take you!" The revenant stood up and shouted back, grinning, "You instead, you instead!" When the man reached the Tõikvere inn, he still heard rattling in the aspens and later on someone whined like a dog. Ever since that no one has seen the revenant again. The wolves probably did eat her." (H II 9, 520/1 (12) Haljala, 1889) 
This paper was presented at the Holy Land International Congress for Folklore and Culture, held in Nazareth on December 27, 1992 till January 3, 1993.

Manuscripts referred

$\mathrm{ERA}=$ Folklore collection of the Estonian Folklore Archives (1927-1944)

$\mathrm{H}=$ Folklore collection of J. Hurt (1860-1906)

\section{References}

Aa S = Aarne, Antti 1918. Estnische Märchen- und Sagenvarianten. FF Communications No. 25. Hamina.

Eisen, Matthias Johann 1897. Kodukäijad. Katse nende iseloomu seletamiseks ja 40 juttu hingede ilmumisest. Narva.

Hiiemäe, Mall 1990. Souls' Visiting Time in the Estonian Folk Calendar. Traditional Folk Belief Today. Conference dedicated to the 90th anniversary of Oskar Loorits. Abstracts, pp. 35-38. Tartu. Loorits, Oskar 1949. Grundzüge das estnischen Volksglaubens. I. Skrifter utgivna av Kungl. Gustav Adolfs Akademien för folklivsforskning 18:1. Lund.

Loorits, Oskar 1949. Grundzüge das estnischen Volksglaubens. III. Skrifter utgivna av Kungl. Gustav Adolfs Akademien för folklivsforskning 18:3. Lund.

Simonsuuri, Lauri 1961. Typen- und Motivverzeichnis der finnischen mythischen Sagen. $F F$ Communications No. 182. Helsinki.

Viluoja, Eha 1982. Demonic Dead in Estonian Folk Tradition. Suomalais-neuvostoliittolainen itämerensuomalaisen filologian symposiumi 30.8.-2.9.1982. Jyväskylä. Esitelmien referaatit, pp. 118 - 119. Jyväskylä. 